\title{
Von Willebrand disease type 1
}

INSERM

\section{Source}

INSERM. (1999). Orphanet: an online rare disease and orphan drug data base. Von Willebrand disease type 1. ORPHA:166078

Type 1 von Willebrand disease (type 1 VWD) is a form of VWD (see this term) characterized by a bleeding disorder associated with a partial quantitative plasmatic deficiency of an otherwise structurally and functionally normal Willebrand factor (von Willebrand factor; VWF). 